*ak RMIS View/Frint Document Cover Sheet tow

This document was retrieved from the Documentation and Records Manaqement (DRM) ISEARCH System. It is intended for Information only and may not be the most recent or updated version. Contact a Document Service Center (see Hanford Info for locations) if you need additional retrieval information.

Accession \#: D196105384

Document \#: WHC-SA-3073-FP

Title/Desc:

CAREFUL WHERE YOU DIG

Pages: 12 


\section{Careful Where You Dig!}

D. S. Kelly

Westinghouse Hanford Company

D. A. Nawarynsky

ICF Kaiser Hanford Company

Date Published

March 1996

To Be Published in

Civil Engineering

Prepared for the U.S. Department of Energy

Assistant Secretary for Environmental Management

\footnotetext{
(2)

Westinghouse

P.O Box 1970

Hanford Company Richland, Washington
}

Management and Operations Contractor for the

U.S. Department of Energy under Contract DE-ACO5-87RL10930

Copyright Licenm By acceptance of this axticle, the publisher mdlor recipient acknowlodots the

U.S. Govemment'e right to retein a nonexclusive, roydty-tree license in and to any copyright covoring this paper.

Approved for public release 
IEGAL DISCLAMER

This report was prepared as an sccount of work sponsored by an agency of the Unitod States Government. Neither the United States Government nor any agency thereof, nor any of their employees, nor eny of their contractors, subcontractors or their employees, makes any warranty, express or implied, or assumes any legal liability or responsibility for the eccurecy, completeness, of any third party's use of the results of such use of any information, epparatus, product, or process disclosed, or represents that its use would not infringe privately owned rights. Reference herein to any specific commercial product, process, or service by trade name, trademark, menufacturer, or other wise, does not necessarily constitute or imply its endorsement, recommendation, or favoring by the United States Government or any agency there of or its contractors or subcontractors. The views and opinions of outhors expressed herein do not necessarily state or reftect those of the United States Government or any agency thereof.

This repor has been reproduced from the best available copy.

Printed in the United States of America

DISCLM-2.CHP \{1-91\} 


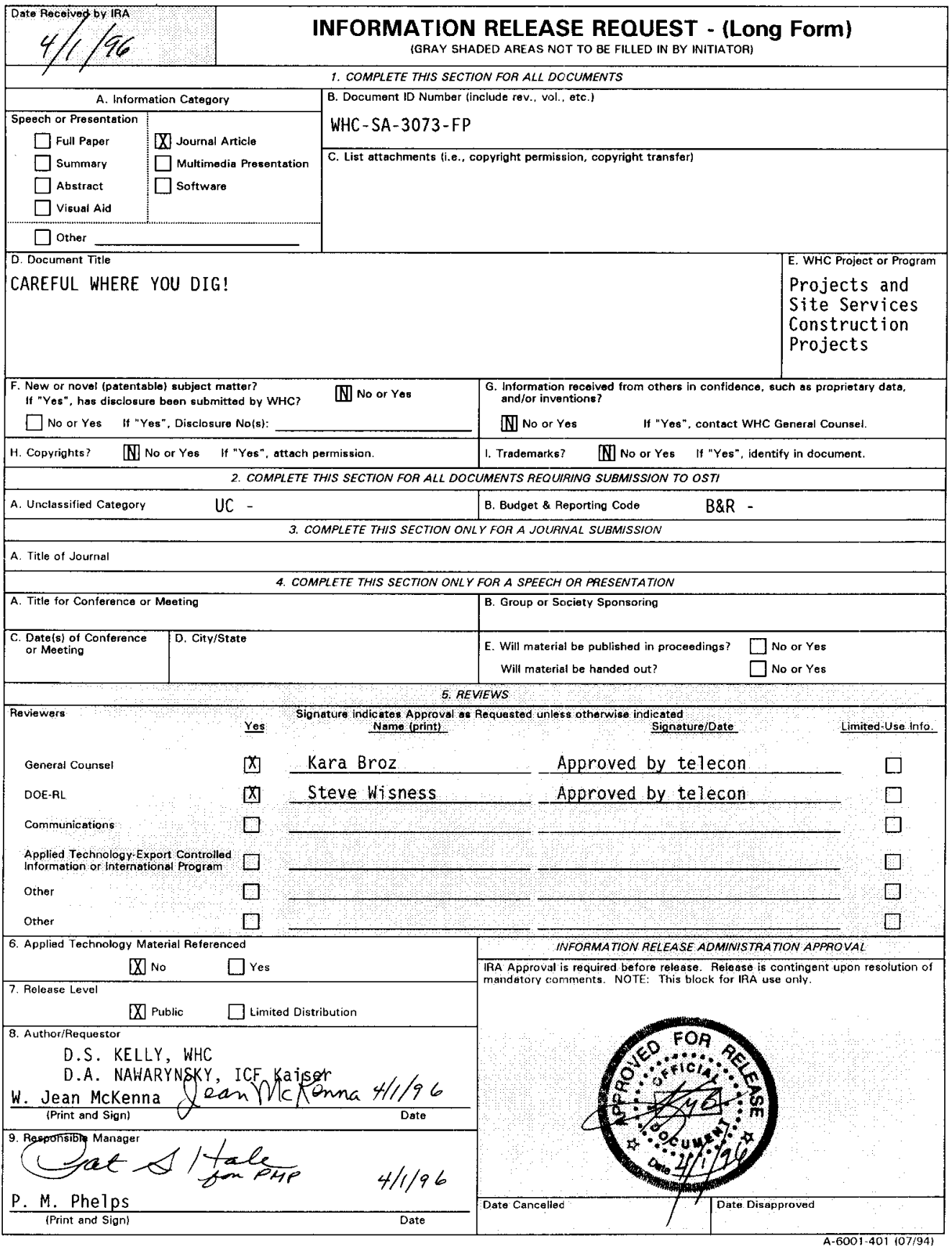


WHC - SA-3073-FP

Document iD Number

10. LEOENDS/NOTCES/MARKINOS (Required by WHCCM 3.4 or Rovieworl Aoviewer indicates applicablo marking to be affixed or removed

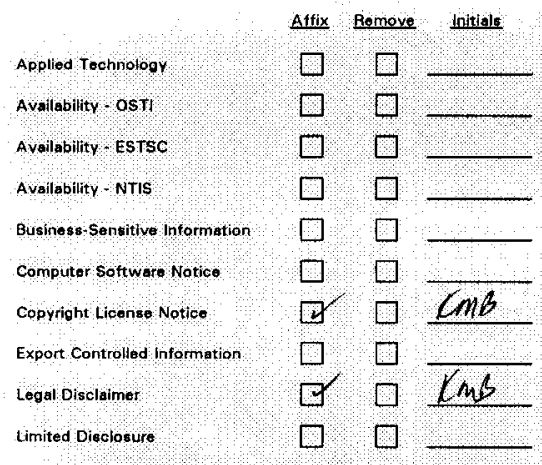

11. MANDATOAY COMMENTS Ltist Only mondetory comments here. All other comment shiall be made on the document and returned to the author.)

\section{offeil uro only}

Patant Stattus

Prodectional tiformation

Programmatic Notice

Proprietary information

Furpose and Use

Thosig/Dinsortetion

Trademark Disclaimer

other

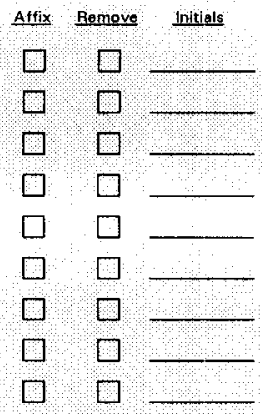

\begin{tabular}{|c|c|c|c|}
$\begin{array}{c}\text { Aoviewer } \\
\text { Print \& Sion) }\end{array}$ & Date & $\begin{array}{c}\text { Resolved by Author/Requestor } \\
\text { (Print \& Sign) }\end{array}$ & Date \\
\hline & & & \\
\hline & & & \\
\hline & & & \\
\hline & & & \\
\hline & & & \\
\hline & & & \\
\hline
\end{tabular}




\section{Careful Where You Dig!}

David S. Kelly, Westinghouse Hanford Company

Daria A. Nawarynsky, ICF Kaiser Hanford Company

Improved excavation techniques help contractors at former nuclear weapons site avoid digging up the past.

The Department of Energy's Hanford Site is an excavator's nightmare. It's one of the country's oldest nuclear sites, with facilities that were built in the rush to win a world war and then a decades-long arms race. During World War II the reactors and process facilities at Hanford were constructed with utmost secrecy. For instance, the site was divided up into various, distinct processing areas -- each with its own separate survey coordinate system to confuse an invading enemy.

In 1989 when the Cold War ended, Hanford began its metamorphosis from top secret defense site to the nation's largest and most complex nuclear waste cleanup project. National defense urgency and past environmental and as-built standards of the time left a legacy of chemical discharges and semi-hidden utilities. Also, the new cleanup mission included a new interest in privatization and outsourcing for engineering and services. This brought an influx of new contractors and personnel with no work experience of the Hanford Site.

In the 50-year history of Hanford, various government agencies, contractors and their policies have come and gone. As federal budgets rose and fell, so did the accuracy of as-built documentation. At one point, jobs below $\$ 150,000$ in value were not even documented as they were built because it wasn't considered cost-effective.

Many utilities were field-routed, leaving no dependable as-built drawings. To be cost-effective, adjacent construction projects often shared a common excavation, both adding underground lines to the same trench. This led to mixed confidence levels in the accuracy of the as-builts.

Is it safe to dig?

Excavation is one of the most dangerous activities in the construction industry. It's the largest single cause of reportable gas and hazardous liquid pipeline accidents in the United States. From 1988 through 1993, for example, 33 percent of the 1,456 reported gas pipeline incidents were caused by excavation damage by persons other than the operator or its contractor. These incidents resulted in 35 deaths, 151 personal injuries, and more than $\$ 42.5$ million in property damage.

At Hanford the consequences of digging in the wrong place can be severe. A series of excavation-related events - including a near-miss in which a buried 13.8 kilovolt cable was severed-caused Hanford Site contractors to re-examine their excavation safety practices. Improvement was no easy task, because operation of the site is shared by multiple contractors. 


\section{Solutions identified}

A grass-roots contractor team assembled tools in the form of process and equipment improvements to help the site's construction workers dig safely. Westinghouse Hanford Company, the site Management and Operations contractor, and ICF Kaiser Hanford Company, the Architect/Engineer, Construction Management and Base operations contractor, are leading a multi-contractor effort with the support of their customer, the U.S. Department of Energy. They're using the latest government and industry techniques to upgrade excavation safety. Their approach may apply to your situation.

Input from a host of sources was gathered. Employee meetings were held, past accident investigations were reviewed, and state and federal laws were examined. With the help of off-site independent experts, the contractor team identified the best technology industry had to offer. Out of this focused research effort, corrective actions and a series of coordinated process, training and technology improvements was developed.

First on the list of improvements was consolidation of the multiple site-wide excavation clearance and release procedures into one site-wide policy. It includes common forms, logs and approval strategies based on the best industry practices. This is a significant step, because each of the site's multiple contractors has historically managed its own affairs.

Exhaustive interference research is conducted to locate underground hazards. Besides the usual drawing research, reviews of aerial photographs from previous years, interviews with retired employees - even pre-design scans and potholing (excavating down) to suspected utilities - have been employed in the effort.

Such up-front research helps designers avoid interferences, and saves project money. This early information of known or suspected utilities is recorded on composite "interference maps" and typical site plan drawings. This research may include other areas of concern such as hazardous waste contamination sites, Native American cultural areas or biologically sensitive areas.

These so-called "interference maps" are used as communication tools throughout the process. For instance, map locations are used as a starting point to: assist the scan crew; confirm interference locations by utility owners; and record finds and as-built locations. All changes are recorded as they are found, and the longer-term strategy is to eventually use this real-time mapping information to supplement the project as-built program.

\section{A unique place}

The job of the Hanford Site has changed completely from defense production to environmental cleanup of the nuclear waste and contamination left behind from its original mission and research and development. Along with a surge of cleanup activity has come the realization that the as-built locations of underground hazards were approximate at best. 
Utilities were not confined to standard utility corridors. Every imaginable system was buried, including radioactive and non-radioactive chemica? pipelines, steam and water utilities, tanks of various sizes up to a million gallons, security systems and cables for signal, power, fiber-optics, telephone and computer applications as well as the monitoring of process facilities and radioactive tank farms.

The more critical lines and tanks were documented with some level of accuracy, but the locations and depths of typical utilities and secondary systems were approximate.

As part of the hazardous waste cleanup effort, agreements were reached between federal and state regulators on the types and timing of the work. Strict schedules and budgets had to be maintained because of penalties and fines associated with missing legally-enforceable milestones and 1 imited funding. Solutions had to be invented to locate, identify, and document the underground hazards.

\section{Mapping solutions}

Because of the nature and inconsistent utility mapping at the federal site, it's not feasible to totaliy rely on the Washington State's "one-call" Utilities Underground Location Center service. To compensate for this, and to encourage eventual transition to full use of the one-call service, a site excavation coordinator position was created.

This coordinator logs in all excavations and reviews each project's interference research, scanning, excavation techniques, work releases and approvals, and planning for as-built documentation. This interaction allows an efficient cross-site sharing of accident prevention lessons learned, centralized data collection, focused excavation policy interpretation, and good management of safety-related process improvements.

Future Utilities Underground Location Center subscription will require increased owner involvement and accountability for utility locations. In the past, projects were held accountable for locating all the existing utilities, but involvement by the facility or system owner was limited to review of the project design media and permit approval. This method was inefficient, as each project design was forced to repeat much of the same interference research, often with different levels of success.

The improved system requires the facility or system owner to not only confirm that the design indicates all the known interferences, but also verify the location in the field. This has placed a heavy burden on the utility owners, but it also provides a much-needed incentive to assure that the asbuilt drawings are correct. The project excavation contractors are still accountable for positively identifying the interference through hand excavation. 
Identifying the system owners/operators has been critical to this effort. Many of the secondary systems (e.g. branch circuits) are shared between facilities with no clear custodian. When this is discovered, the site excavation coordinator works with the system customers to identify an owner. Recent changes in personnel responsibilities because of a contract consolidation between Westinghouse Hanford and ICF Kaiser has further complicated identification of system owners/operators.

\section{Technology Solutions:}

An aggressive technology search and training program was implemented. The site updated its subsurface interference scan capabilities, looked at new trenchless repair and replacement excavation technologies, investigated noninvasive techniques, and improved the capabilities for as-built documentation.

Scan capabilities were improved through better crew training, new equipment and better use of data. A nationally known expert was brought in to teach a class on subsurface utility scan techniques, which included hands-on instruction in the use of the latest locating equipment.

Scan crews are provided with a composite interference map, made up of all available knowledge of the known interferences in the area. This assists the scan crew in knowing where to start looking for existing utilities. Now, since they are not on a "treasure hunt," their success ratio has increased significantly.

The scan process includes use of multiple scan equipment technologies based on target type and field conditions; cross-checking of scans using alternative scan technology; field calibration tests of scan equipment; computerized scan data mapping (to detect hard-to-locate items); and geophysical analysis for three-dimensional mapping and pre-scan soil characterization support.

Non-intrusive detection methods used at Hanford include: electromagnetic techniques to supplement the use of Ground Penetrating Radar (GPR). When verification or "ground-truthing" is appropriate, vacuum excavation is used to supplement conventional intrusive methods (shovel, backhoe, drill).

As the aging Hanford utility systems need repair, the team encourages avoiding excavation through increased use of trenchless excavation techniques. This minimizes the risk of excavation or avoids it all together. Two techniques used successfully on site are sliplining and horizontal boring.

The sliplining technique involves the inverting of a pre-heated resincoated fabric sieeve, which is then cured in place using steam. A remotely operated robot is then used to cut, and tie in the lateral branch 1 ine openings. This technique allows long runs of pipe to be refurbished, with minimal excavation. 
The horizontal boring technique is used to route pipes under roads. The site is investigating other trenchless technologies, such as: steerable directional drilling; pipe ramming, a technique where the pipe is vibrated through the soil; pipe bursting, where the pipe is literally cut, with a new replacement pipe drawn in behind the cutter. This last technique does require pit excavations to re-tie-in the laterals.

If potholing excavation is necessary to locate interferences or expose energized lines, the hazard is reduced by using non-invasive excavation techniques such as vacuum excavation and air lances to supplement careful hand excavation.

Vacuum excavation has been used with great success to safely remove soil without damaging utilities or putting workers in harm's way. A truck-mounted vacuum, drawing 17,000 cubic feet per minute of air and dirt through an 8inch-diameter suction tube, bores down to the utilities that cross a planned excavation.

The suction tube is made of polyvinyl chloride (PVC), so the operator is protected from potential electrical shock from buried power lines. Once the pothole is vacuumed, a pipe is placed down the hole until after the

construction is complete, to positively locate the find. If questions arise later about the type or depth of the utility, it's a simple matter to peer down the pipe to confirm any details.

This technique is currently limited to non-contaminated soils. Site regulations require contractors to hand-excavate within 5 feet of the anticipated location of any known utility to positively locate it. Once vacuum excavation locates the utility, the rest of the trench can be more cost-effectively machine-excavated instead.

Construction delays and changes are avoided if the "potholing" is performed during design, but this technique is not without limitations. Temperatures of 35 degrees Fahrenheit or colder, combined with high humidity, will block the suction tube with frost. Rocky soil can also cause complications, depending on the average diameter of the encountered cobbles. But these are manageable limitations.

\section{Looking ahead}

Several different mapping systems have been used over the years, and the site contractors are working to consolidate these systems and better communicate the as-built configurations. The site has adopted an "as-built, as you go" philosophy.

Some of the as-built improvements being implemented are documentation of finds, coordination of mapping data sets, differential global positioning system locators, photogrammetry and use of a standardized coordinate grid system. 
DOE and its contractors are firmly committed to locating and identifying these hidden hazards to ensure no radioactive or hazardous material release to the environment could occur. Even more important is worker safety, as many of the burjed utilities could cause injury or even death.

Before the safety improvement effort began, there were multiple contractors with multiple procedures. Now, one procedure applies to all contractors on the entire site, and all employees understand their responsibilities.

The team has tackled the immediate problems and laid down the process and organizational foundation to carry the excavation safety program into the future. It can be changed and further improved as new technologies become available and contractual arrangements change.

The site is moving toward eventual full use of the Utilities Underground Location Center, and team members and the contractors they represent are committed to seeking out and addressing the hazards, to keep Hanford a safe place to excavate. 
The Hanford Site - why it's unique

The Department of Energy's Hanford Site is a remote 560-square-mile federal reservation in the arid southeast corner of Washington State. It's a former plutonium production site now in the midst of a multi-billion-dollar environmental cleanup effort.

In 1942, the Hanford Site was seen as the perfect $p$ lace to build urgently needed plutonium production reactors. The abundance of clean water, electrical power, rail service and heavy aggregate for making concrete justified the government's action to condemn the farms and villages in the area for this secret project.

Just 28 months after the March 1943 groundbreaking, plutonium from Hanford was used in the July 1945 Trinity bomb test, and on Aug. 9, 1945, a bomb with Hanford material was detonated over Nagasaki, Japan, bringing an end to the war with Japan.

All of Hanford's reactors and process facilities were constructed in the utmost secrecy. It wasn't until after the bombing of Hiroshima and Nagasaki that many of the workers and their families were told what the Hanford plants really produced.

Around 1989, as the Cold War ended and the country faced an excess supply of plutonium, Hanford's mission changed from top-secret weapons production to radioactive and hazardous waste cleanup.

The job at hand includes building facilities to process these wastes. But past practices have left a legacy of radioactive and hazardous discharges and semi-hidden utilities to challenge today's Hanford excavators. 